\title{
The translator's preface as a paratextual device in Malay-English literary translations
}

The International Journal for Translation \& In erpreting Research trans-int.org
Haslina Haroon

Universiti Sains Malaysia, Malaysia

haslina@usm.my

DOI: 10.12807/ti.109202.2017.a07

\begin{abstract}
In the context of Malaysia, research in the field of Translation Studies has traditionally focused on the analysis of texts, which often involves a comparison between source texts and their translations. Very little attention is given to the area of the analysis of paratexts, which is not surprising considering that paratexts exist only on the periphery of the text and are therefore thought to be less important. Given the paucity of research in this area, this preliminary study focuses on one type of paratext, which is the translator's preface. More specifically, the aim of this study is to examine the form and content of these introductory notes in translations published in Malaysia and to discuss the functions served by the contents of these notes. For this purpose, translators' prefaces from translations published in Malaysia were collected and examined. The discussion in this paper focuses on the content and functions of the prefaces. It is argued that the translator's preface plays an important role not only in facilitating the reception of the translated text by providing vital information to the readers, but also in making the translator visible and his/her voice heard.
\end{abstract}

Keywords: paratext, translated text, translator's preface, translator's note, visibility

\section{Introduction}

Research in the field of Translation Studies in Malaysia generally has tended to focus on analysis of both source texts and their translations, focusing, for example, on the translator's approach and strategies in translating. This is understandable considering that such an analysis can provide useful insights into the choices made by the translator in the process of presenting the text to a new readership. Such textual analysis, in turn, can help translation trainees learn about the challenges and difficulties in translating. The analysis of paratexts, however, has received relatively less attention. This is not entirely surprising, considering that paratexts exist only on the periphery of the translated text and are therefore thought to be of little or no importance compared to the text. Given the paucity of research in this area, this paper focuses on an analysis of paratexts, more specifically translator's prefaces in literary translations in the context of Malaysia. 
Paratexts is defined by Genette as "those liminal devices and conventions, both within the book (peritext) and outside it (epitext), that mediate the book to the reader: titles, and subtitles, pseudonyms, forewords, dedications, prefaces, intertitles, epilogues and afterwords" (Genette, 1997, p. xviii). They are thus texts which accompany the main texts. Based on Genette's definition, paratexts can be divided into two: peritexts and epitexts. Peritexts are those elements such as the title and the preface which are located in the text, while epitexts are those elements such as interviews and reviews which are located outside the text (Genette, 1997, p. 5). This article focuses on one type of peritext, which is the translator's preface, also sometimes referred to as the translator's note. It is here that the translator normally provides certain information regarding the source text and discusses certain issues regarding the translation.

Translators' prefaces are quite rare today. Translators, however, have long engaged in the practice of discussing their source texts and their translation choices. Munday explains that "one of the characteristics of the study of translation is that, certainly initially, it was based on the practice of translating; much early writing was by individual translators and directed at explaining, justifying or discussing their choice of a particular translation strategy" (2009, p. 1). Munday acknowledges the value of studying these prefaces and asserts that "translation prefaces are a source of extensive information on the translation methods" $(2016$, p. 52). A compilation of these early prefaces can be seen, for example, in the publications by Steiner (1975) and Robinson (2002).

The present paper aims to examine translators' prefaces in literary translations from Malay into English. The aim specifically is to determine the form of these prefaces and the information they contain, and ultimately to determine the function of the prefaces. In the following sections, I will first provide a review of research focusing on paratexts in translated texts in the field of Translation Studies. I will then proceed to the presentation of my corpus, followed by a discussion of the types of information contained in the prefaces examined. I conclude by summarizing the study and by suggesting other areas involving the study of paratexts, which could be further explored.

\section{The analysis of paratexts in Translation Studies}

In the context of Translation Studies, the importance of the analysis of the paratext is evident in the number of studies carried out in this specific field. The main focus of these studies appears to be the role and function of paratextual elements. Kovala (1996), for example, examined paratextual elements such as titles, author's and translator's names, series, prefaces, blurbs, notes, advertisements and illustrations found in Finnish translations of Anglo-American literature from 1890-1939. Based on his analysis, it was found that the use of these paratextual elements reflects a religiousconservative ideology.

The use of paratextual elements was also the focus of the study by TahirGürçağlar (2002). Focusing on the Turkish context, she looked into how paratextual elements are used to present English classics in Turkish translations to new readers. Additionally, the analysis of the paratexts offered some clues about the definition of translation that was adopted at that time. 
Both these studies are important in that they clearly demonstrate how an analysis of paratexts can be used in historical translation research.

The important role of paratexts was also explored by Marín-Dòmine (2003). Through an examination of the paratextual differences between the British translation and American retranslation of a Catalan novel, she was able to show how paratexts play a role in shaping the way the translated text is received by the target culture, thus highlighting the importance of paratextual elements in a translated text.

Some scholars exploring this area of Translation Studies have chosen to focus on a specific paratext. Paloposki (2010), Toledano Buendía (2013) and Sanchez Ortiz (2015), for example, focused their attention on notes provided by translators which normally appear in the form of footnotes. Adopting a sociological approach and focusing on the agency of the translator, Paloposki (2010) examined footnotes in Finnish translations from 1870-1929, looking specifically at their distribution, forms and functions. She asserted that footnotes are "the one spot in the translation that is clearly the translator's own voice" (2010, p. 87), and that a study of these paratextual elements would be able to offer information about their use by different translators and in different genres.

Translator footnotes are also the focus in the study carried out by Sanchez Ortiz (2015), with emphasis on their use in literary translations from English into Spanish. It was found in this study that translators differ in their use of footnotes, and this difference is largely due to the translators' own judgement of the needs of their target readers.

Toledano Buendía (2013) also looked at notes provided by the translator but did not limit her study to the use of footnotes. She defined 'notes' in a specific way, that is, as "statements of variable length which are always connected to more or less definite segments of the text and they are usually found printed at the bottom of the page or in its margins, although they can also be included at the end of each chapter or book" (Toledano Buendía, 2013, pp. 150-151). Toledano Buendía (2013) described the notes in terms of their place and time, their sender and addressee and their functions. Based on the analysis carried out, there appear to be two types of translator notes: (1) notes which supplement the text and which have an informative function, and (2) notes which express the translator's opinions and attitudes (Toledano Buendía, 2013, pp. 156-161).

Other scholars have chosen to focus on translators' notes in a different form. Dimitriu (2009), McRae (2012) and Norberg (2012), for example, examined notes which appear in the form of prefaces. Again, the role played by the specific paratextual element became the focus of the studies. In his examination of 65 prefaces from literary and non-literary translations published in Romania, Dimitriu (2009) found that the translators' prefaces serve three different functions: (1) an explanatory function, (2) a normative/prescriptive function, and (3) an informative/descriptive function. More specifically, the translators use the preface to explain their choice of text and their selection of strategies for specific problems in the text. The prefaces also provide the opportunity for the translators to convey or prescribe certain guidelines to be followed when translating. Finally, the translators also use the preface to describe the source text and its sociocultural contexts.

Proceeding along the same lines as Dimitriu (2009), McRae (2012) examined the content of prefaces in terms of their functions. The focus specifically was on 84 translations of literary fiction into English. McRae 
(2012), however, adopted a specific definition of prefaces. In her study, they include "translators' prefaces, introductions, notes, afterwords or any other commentary preceding or following a translation written by the translator. It does not include footnotes or endnotes" (McRae, 2012, p. 66). Based on the analysis, it was found that the prefaces serve the following functions: "(1) foregrounding differences of cultures and languages, (2) promoting understanding of the source culture, (3) promoting understanding of the translator's role and intervention, (4) helping critics assess the quality of the translation and (5) being useful as process documentation" (McRae, 2012, pp. 80-81).

Approaching the study of prefaces from the point of view of translation sociology, Norberg (2012) examined translators' prefaces in fictional works translated into Swedish and presented his general observation about the frequency of prefaces, the titles given to these metatexts, and their content. In terms of the translators' comments in the prefaces, Norberg (2012, p. 103), drawing on role theory, states that these comments can appear in the form of offensive or defensive statements. He further explains that "by offensive, I mean comments on translation decisions which appear obvious and undeniable, and which show little role distance. By defensive I mean statements that anticipate possible objections to certain translation decisions, and which, therefore, express a greater degree of role distance" (Norberg, 2012, p. 103). It must be noted that Norberg's (2012) analysis of translator prefaces in the Swedish context is complemented by the opinion and views of publishers regarding prefaces in translation. This, according to Norberg, is important because "they have considerable power in deciding whether such texts should exist or not, and if they should exist, in deciding who should write them, where they should be placed, what they should contain, and how they should be formulated" (2012, p. 112).

Both Norberg (2012) and Dimitriu (2009) also discuss the practical aspects of the translator's account as presented in the preface. Norberg (2012, p. 104), for example, states that the translator's preface provides the opportunity for the translator to "strengthen his/her reputation", "satisfy the translator's desire to write about the translation task without being immediately challenged" and "anticipate and prevent criticism from reviewers and readers". The last point, however, is a double-edged sword. While the translator may be able to prevent criticism from reviewers by discussing his translation strategies, this approach runs the risk of "exposing translation principles and procedures that may invite criticism from reviewers and others" (Norberg, 2012, p. 104).

An analysis of the translators' prefaces may also enable translation scholars and researchers to infer translation norms (Dimitriu, 2009, p. 202) and translation ideals (Norberg, 2012, p. 115) which prevail at a particular period of time. Both Dimitriu and Norberg, however, agree that this is only possible with a large number of prefaces and through a detailed comparison between the preface and the actual translations. Comparison between the preface and the actual translation may also enable us to check on "the reliability of the translation principles expressed in the comments on the translations in translators' prefaces" (Norberg, 2012, p. 115).

Finally, Dimitriu (2009, p. 203) also suggests that the analysis of prefaces could be useful to translator trainees in that they can learn from and adopt the guidelines provided in the preface. 


\section{Method}

The aim of this paper is to examine translators' prefaces in literary translations from Malay into English to determine the form and content of the prefaces and ultimately their function. To some extent, this study is carried out along the lines of Dimitriu's (2009) and McRae's (2012), although involving significantly fewer texts. It must be noted that McRae (2012) began with an initial corpus of 810 translations. Out of this number, only $10 \%$ or 84 translations contained prefaces which discussed the translations and which became the final corpus of the study. The method adopted by McRae (2006) proceeds along the suggestion regarding inclusiveness put forth by Paloposki (2010). In examining the use of footnotes in translated fiction in Finland, she suggested that "the selection of books had to be inclusive, in the sense that not only books with footnotes would be studied: to reveal patterns of annotation, it was also necessary to find out when and in what instances footnotes were not used" (Paloposki, 2010, p. 88). The aim of this study, however, is not to look at patterns in the use of prefaces. Therefore, the inclusiveness suggested by Paloposki (2010) is not deemed relevant in this study. As such, the texts making up the corpus of this preliminary study are texts which are specially selected because of the presence of the translator's preface in them.

Hosseinzadeh (2015) provides a more comprehensive framework for the study of what she refers to as 'translatorial prefaces'. The model, which is developed based on an analysis of 104 prefaces, provides a framework for the investigation of the form, content and function of prefaces. Based on the analysis, it is concluded that the form of the prefaces can be studied in terms of their title, length, pagination and signature (Hosseinzadeh, 2015, p. 315). The content of the prefaces, meanwhile, can be classified according to the themes which emerge from the prefaces (Hosseinzadeh 2015, p. 316). In terms of their function, Hosseinzadeh draws on the typology provided by Dimitriu (2009) with some additional categories, which combine the three basic functions mentioned by Dimitriu (Hosseinzadeh, 2015, p. 317). In this study, Hosseinzadeh' (2015) model is used; nevertheless, Dimitriu's (2009) basic classification is employed in discussing the function of the prefaces.

\section{Analysis of the translators' preface in translations from Malay into English}

This preliminary investigation looks at the form, content and function of nine prefaces from literary translations from Malay into English. As mentioned earlier, the texts making up the corpus of this preliminary study are texts which are specially selected because of the presence of the translator's preface in them. It must also be pointed out that all the texts are novels by authors who are considered prominent literary figures in Malaysia, all born in the 1930s or 1940s, except one, Ishak Haji Muhammad, who was born in 1901. As such, the presence of the translator's preface in each of the translations is perhaps not entirely coincidental.

All the translations were published in Malaysia, with the exception of one translation, which was published in Singapore. In terms of year of publication, three of the translations were published in the 1970s, four in the 1980s, and two after the year 2000. The details of these texts are shown in Table 1 below. 
Table 1: Selected literary translations from Malay into English which contain the translator's preface

\begin{tabular}{|c|c|c|c|c|c|}
\hline No. & $\begin{array}{c}\text { Title of English } \\
\text { Translation and } \\
\text { Title of Malay } \\
\text { Source Text }\end{array}$ & Author & Translator & $\begin{array}{l}\text { Publication } \\
\text { details }\end{array}$ & $\begin{array}{l}\text { Title of } \\
\text { metatext }\end{array}$ \\
\hline 1. & $\begin{array}{c}\text { No Harvest but a } \\
\text { Thorn } \\
\text { (Ranjau Sepanjang } \\
\text { Jalan) }\end{array}$ & $\begin{array}{l}\text { Shahnon } \\
\text { Ahmad }\end{array}$ & Adibah Amin & $\begin{array}{c}\text { Kuala Lumpur: } \\
\text { Oxford } \\
\text { University Press, } \\
1972\end{array}$ & $\begin{array}{l}\text { Note on the } \\
\text { Translation }\end{array}$ \\
\hline 2. & Salina (Salina) & $\begin{array}{l}\text { A. Samad } \\
\text { Said }\end{array}$ & Harry Aveling & $\begin{array}{c}\text { Kuala Lumpur: } \\
\text { Dewan Bahasa } \\
\text { dan Pustaka, } \\
1975\end{array}$ & $\begin{array}{c}\text { Translator's } \\
\text { note }\end{array}$ \\
\hline 3. & $\begin{array}{l}\text { Rope of Ash } \\
\text { (Rentong) }\end{array}$ & $\begin{array}{l}\text { Shahnon } \\
\text { Ahmad }\end{array}$ & Harry Aveling & $\begin{array}{c}\text { Kuala Lumpur: } \\
\text { Oxford } \\
\text { University Press, } \\
1979\end{array}$ & $\begin{array}{l}\text { A Note on the } \\
\text { Translation }\end{array}$ \\
\hline 4. & Crisis (Krisis) & Alias Ali & $\begin{array}{l}\text { Barclay M. } \\
\text { Newman, Jr. }\end{array}$ & $\begin{array}{c}\text { Kuala Lumpur: } \\
\text { Dewan Bahasa } \\
\text { dan Pustaka, } \\
1980\end{array}$ & $\begin{array}{c}\text { Translator's } \\
\text { note }\end{array}$ \\
\hline 5. & $\begin{array}{c}\text { The Last Days of } \\
\text { an Artist } \\
\text { (Hari-hari Terakhir } \\
\text { Seorang Seniman) }\end{array}$ & $\begin{array}{c}\text { Anwar } \\
\text { Ridhwan }\end{array}$ & Harry Aveling & $\begin{array}{c}\text { Kuala Lumpur: } \\
\text { Dewan Bahasa } \\
\text { dan Pustaka, } \\
1982\end{array}$ & $\begin{array}{c}\text { Translator's } \\
\text { note }\end{array}$ \\
\hline 6. & $\begin{array}{l}\text { The Son of Mad } \\
\text { Mat Lela } \\
\text { (Anak Mat Lela } \\
\text { Gila) }\end{array}$ & $\begin{array}{l}\text { Ishak Haji } \\
\text { Muhammad }\end{array}$ & Harry Aveling & $\begin{array}{c}\text { Singapore: } \\
\text { Federal } \\
\text { Publications, } \\
1983\end{array}$ & $\begin{array}{c}\text { Translator's } \\
\text { note }\end{array}$ \\
\hline 7. & Saga (Saga) & $\begin{array}{c}\text { Abdul Talib } \\
\text { Mohd. } \\
\text { Hassan }\end{array}$ & $\begin{array}{l}\text { Robert. B. } \\
\text { Stuebing, } \\
\text { Solehah Ishak } \\
\text { \& Ungku } \\
\text { Maimunah } \\
\text { Mohd. Tahir }\end{array}$ & $\begin{array}{c}\text { Kuala Lumpur: } \\
\text { Dewan Bahasa } \\
\text { dan Pustaka, } \\
1987\end{array}$ & $\begin{array}{c}\text { Translator's } \\
\text { note }\end{array}$ \\
\hline 8. & $\begin{array}{c}\text { Tales of Ogonshoto } \\
\text { (Naratif } \\
\text { Ogonshoto) }\end{array}$ & $\begin{array}{l}\text { Anwar } \\
\text { Ridhwan }\end{array}$ & Solehah Ishak & $\begin{array}{c}\text { Kuala Lumpur: } \\
\text { Dewan Bahasa } \\
\text { dan Pustaka, } \\
2004\end{array}$ & $\begin{array}{c}\text { Translator's } \\
\text { note }\end{array}$ \\
\hline 9. & Salina (Salina) & $\begin{array}{l}\text { A. Samad } \\
\text { Said }\end{array}$ & Lalita Sinha & $\begin{array}{c}\text { Kuala Lumpur: } \\
\text { Institut } \\
\text { Terjemahan \& } \\
\text { Buku Malaysia, } \\
2013\end{array}$ & $\begin{array}{c}\text { Translator's } \\
\text { note }\end{array}$ \\
\hline
\end{tabular}




\subsection{The form of the prefaces}

Where the title of the preface is concerned, it can be seen that the titles of these metatexts are rather similar - Translator's Note, Note on the Translation, and A Note on the Translation. It must be noted that the term 'translator's notes' is also sometimes used to refer to footnotes and other annotations by the translator, as exemplified in the study by Toledano Buendía (2013).

In terms of length, the shortest prefaces are those by Newman (1980) and Stuebing, Ishak \& Mohd. Tahir (1987), with less than 50 words each. The longest prefaces are by Ishak (2004), with approximately 850 words, and Sinha (2013), with approximately 750 words. Three of the prefaces, i.e. by Amin (1972), Aveling (1982) and Aveling (1983), contain from 50 to 100 words. The preface by Aveling (1975) and Aveling (1979) contain 180 words and 280 words respectively.

In terms of pagination, only one preface, by Stuebing et al. (1987) is not numbered in any way. The rest of the prefaces are all numbered using lowercase Roman numerals. This system of numbering sets the prefaces apart from the translations, which are all numbered using Arabic numerals.

Where the signature is concerned, all the prefaces bore the name of the translator at the end, except those by Aveling (1979), Stuebing et al. (1987) and Ishak (2004). Only two of the prefaces are dated, i.e., those by Sinha (2013) and Aveling (1982). While Sinha (2013) dated her preface 'April 2013', there is a gap between the date on the preface of Aveling's (1982) translation, which is ' $3^{\text {rd }}$ November 1980' and the year of the publication of the translation. Aveling (1982) also included the name of the place where he penned the preface, which is Perth.

\subsection{The content of the prefaces}

This section presents an analysis of the content of the translators' prefaces compiled from the nine English translations of Malay literary texts. The analysis involves a careful reading of the prefaces collected. The contents of the prefaces are then categorized according to the themes or topics which emerge from the analysis of these metatexts.

Based on the analysis, the content of the prefaces can be divided into the following themes: (1) Difficulties in undertaking the translation; (2) Information on the translator, (3) Information on the source text, (4) Acknowledgements and dedications, (5) The origin of the translation, (6) Clarification of the title, and (7) General approach and specific procedures in translating.

\subsubsection{Difficulties in undertaking the translation}

Some of the translators began their prefaces by mentioning the difficulties often associated with the act of translating. Ishak mentions that "engaging in translating a source language text into a target language text is never a simple, easy, straightforward endeavour" (2004, p. vii). Sinha's comments, meanwhile, are more specific to the task she undertook, i.e. the translation of the novel Salina, which, according to Sinha, has been acknowledged by scholars as "a giant of the Malay literary canon" (2013, p. ix). Sinha mentions that although the task of translating the novel into English "has been a source of tremendous pleasure and pride", it was at the same time "a daunting task" (2013, p. ix).

Apart from these rather general statements, there were also comments which highlighted specific difficulties. Two of the translators highlighted a 
specific translation challenge, which is the author's use of a specific variety of the local Malay language. Amin notes that "the language of the novel is strongly influenced by the Kedah dialect which presents certain difficulties for the translator" (1972, p. viii). Sinha faced a similar linguistic challenge, which is "the unique phenomenon of 'bazaar Malay' employed by the original author to convey dialogues between people of different ethnic groups of Malaysia, especially the Indian community, which represents a significant 'other', vis-àvis the (Malay) self" (2013, p. x). Sinha's source text is characterized not only by the use of 'bazaar Malay' but also by the inclusion of culture-specific expressions by its author. Sinha mentions that "such expressions, peculiar to the culture of their origin in any language, often represent a perpetual hurdle to successful literary translation" (2013, p. ix).

\subsubsection{Information on the translator}

Only two of the translators highlighted their own work as translators. In her very detailed preface in the 2004 translation of Anwar Ridhwan's work, Ishak begins by telling the readers about her experience as a translator. She informs the readers that she translates both from English into Malay and from Malay into English, although she prefers the latter "as part of an effort to "internationalize" Malay literature and put it on a global stage/arena" (2004, p. vii). Mention was also made of her two previous translations of Anwar Ridhwan's works into English.

Aveling, in his 1979 translation of Shahnon Ahmad's Rentong, mentions another one of his translations, Srengenge, also written by Shahnon Ahmad. Aveling, however, makes specific mention of this novel in order to highlight the different approach he took in Rentong compared to his approach in translating Srengenge. He remarks that "contrary to my practice in translating Srengenge, I have left unchanged the familiar titles Pak (Father), Mak (Mother) and Tok (honorary form of address for elderly men); the reader may decide which is the more effective" (1979, p. xviii).

\subsubsection{Information on the source text}

Some of the translators found it necessary to provide information about the source text to the readers. In his 1982 translation, Aveling tells his readers that "Hari-hari Terakhir Seorang Seniman was awarded first prize in a novelwriting competition held by the Federation of Malaysian Writers Associations (GAPENA) and the Sabah Foundation in 1979" (1982, p. v). Aveling adds that "it is a story of birth and death, of love and suffering, and provides a vivid insight into rural Malay society at the beginning of the Second World War" (1982, p. v). While Aveling makes no mention of the source text in the preface of his 1983 translation, he finds it necessary to tell his readers the significance of the names of some of the characters in the text, which he believes are allegorical in nature (1983, p. x).

Ishak provides a very lengthy account of her text, which is a collection of ten short stories. Her description of the stories, intertwined with a description of the style of the author, takes up more than half of the five-page preface.

Sinha mentions that her Malay source text Salina has been acknowledged by scholars as "a giant of the Malay literary canon" (2013, p. ix). As if to justify this statement, Sinha also informs the readers that Salina has been translated into English, Japanese, Mandarin, Tamil and French (2013, p. x). Sinha also informs her readers that the text has been translated into English twice. This, however, is emphasized by the translator not so much as to 
highlight the importance of the source text but to bring the readers' attention to what she perceives as deficiencies in the two earlier translations (see discussion in 4.2.5) and subsequently to justify the need for a third English translation of the text.

\subsubsection{Acknowledgements and dedications}

Two of the translators found it necessary to acknowledge certain individuals who assisted them in their translations. Newman, in his translation, acknowledges a Malay friend, Amdun Husain "who made a careful review of the English translation and corrected many of my blunders" (1980, p. v). It is assumed that these "blunders" mentioned by Newman are due to the fact that he is not a native speaker of Malay, the language of the source text. Meanwhile, Sinha too touches on the language issue in her acknowledgement. Based on the awareness that her English translation may contain a few Malaysian-English expressions which may come across as odd to some of her readers, Sinha addresses this issue by enlisting the help of "David Collett, a native English speaker who has acquired an interest in, and I believe some degree of acculturation of, the local culture and language by living and working here for many years" (2013, p. xi).

Also seen in the prefaces are the translators' expressions of gratitude. Aveling, for example, expresses his gratitude to Prof. A. Teeuw of Leiden University for granting him permission to use part of the talk he gave as an "Introduction" in the translation (1975, p. xiii). The expression of gratitude is also seen in the preface of Aveling's 1983 translation, in which a number of people are mentioned for their assistance in the translation. Sinha too makes a point to convey her gratitude, specifically to the original author, the publisher and her mentor (2013, p. xi).

Besides acknowledgements and expressions of gratitude, some of the prefaces also contain dedications, for example, in Aveling's 1975 and 1982 translations and in Ishak's 2004 translation.

\subsubsection{The origin of the translation}

For some of the translators, the origin of the translation was important. Because of this, the readers are told in the preface how the translations came about. Aveling (1982), for example, very briefly mentions that it was in fact the publisher, Dewan Bahasa dan Pustaka, who approached him and requested for the translation of Hari-hari Terakhir Seorang Seniman into English to be carried out.

Sinha (2013) provides a more detailed explanation of the history behind her translation of the Malay novel Salina, which had previously been translated twice into English. Sinha explains that "the seed of the idea for this translation can be traced back to my Master's thesis, which was a scrutiny of the two existing English translations of the work, in which I focused on the culture-specific expressions (or CSE) in Salina" (2013, p. ix). Sinha then proceeds to give details about the two earlier translations of the novel. With reference to this, Norberg (2012, p. 106) notes that "prefaces in retranslations sometimes mention previous translations and/or translators, but if any criticism at all is directed at the previous translators - and this is usually not done - it is most often expressed in very polite terms". In Sinha's case, she comments in her preface that with regard to the 1975 translation of Salina by Aveling, "the rich cultural nuances of the original work had been reduced, resulting in a feeble version of the powerful Malay masterpiece" (2013, p. ix). 
In the case of the second translation by Hawa Abdullah, Sinha acknowledges that a different approach was taken with regard to the translation, that is, to retain the cultural nuances. Despite the different approach taken, this second translation was also deemed inadequate and, according to Sinha, was "criticized by literary scholars as 'awkward', 'stilted' and riddled with Malaysian-English expressions that impaired the reader's enjoyment" (2013, p. $x)$. Sinha points out that it was her Master's thesis, which analysed the two translations, which led to the publication of her own translation. She explains that it was at the book launch of her study of the two translations in 2006 that the original author "expressed the wish for his work to be translated again this time by me" (2013, p. x). This, according to Sinha, led to the commissioning of the translation in 2010 by ITBM or the Malaysian Institute of Translation and Books.

\subsubsection{Clarification of the title}

Only one of the translators found it necessary to explain the title chosen for the translation. All of the other translators saw no need for such an explanation. This is perhaps due to the fact that the title chosen for each of the other translations is a replication or a close literal translation of the original title.

Aveling provides a rather detailed explanation of the title for his 1979 translation of Shahnon Ahmad's novel entitled Rentong, as can be seen in the following:

The original Malay title, Rentong, means 'burnt to a cinder', 'charred black'...The short word carries a good deal of impact in Malay that none of the literal translations seem to hold, so I have sought an alternative title. The phrase 'no harvest but a thorn', used as the title of previous translation of a novel by Shahnon Ahmad, comes from the English writer George Herbert's poem 'The Collar'. I have taken another phrase from that poem - 'Forsake thy cage,/Thy rope of sands,/Which pettie thoughts have made,...' and adapted it for the title of this English translation (1979, p. xvii).

It is noted that in explaining the reason behind the title for his 1979 translation, Aveling alludes to Amin's 1972 translation of a novel by the same author, Shahnon Ahmad, and provides a brief explanation of the source of the title.

Reference to the title can also be seen in Amin's preface in her 1982 translation. She, however, provides very little information about the title of the translation, except to say "the original title, Ranjau Sepanjang Jalan, may be translated literally as 'Traps along the Way'” (Amin, 1972, p. viii).

\subsubsection{General translation approach and specific procedures}

In almost all of the prefaces, there is mention of the general approach and more specific strategies taken by the translators in carrying out the translation. In her preface in No Harvest but a Thorn, Amin (1972) explains that some Malay words "which echo rhythmically through the novel" have been retained in the translation "in view of their dramatic importance" and that these are explained in footnotes (1972, p. viii). She also adds that "for the rest I have generally tried to keep close to the original as far as possible, with what success no doubt the reader will judge" (p. viii). It remains unclear, however, what the translator means by "keeping close to the original", or the difference 
between "keeping close to the original" and the strategy of retention mentioned by the translator.

Amin's statement is echoed by Stuebing et al. (1987). In their preface, they mention that "in translating Saga we have tried to keep as closely as possible to the original text" (1987, n.p.). Unlike Amin, however, they clarify this statement by mentioning that they have left some elements untranslated in the English translation and that these include Malay titles and forms of address which are explained in the glossary provided at the end of the translation.

The importance of some of the elements in the source text and the way the translators deal with them are also evident in the comments by some of the other translators. Aveling (1979) mentions the use of the procedure of retaining Malay words in the English translation in dealing with religious titles in his translation, Rope of Ash. Unlike Stuebing, Solehah and Ungku Maimunah, however, Aveling provides the meaning of these titles in the preface itself. This same approach can also be seen in Aveling's 1975 translation of Salina. Aveling (1975) explains that some words have been left untranslated in his translation of Salina, and that these are "certain Indian words - exclamations, film and song titles, and the familiar word kampung, used for a village, small urban community or 'neighbourhood' " (1975, p. xiii). He also acknowledges that his translation appears shorter than the original but argues that this is due to the fact that "English relies perhaps more on understatement and the elimination or repetition than Malay does" (Aveling, 1975, p. xiii). In spite of the relatively shorter translation, he asserts that "nothing essential has been omitted" (Aveling 1975, p. xiii). These statements by the translators in their prefaces all point to the fact that they prioritized some kind of fidelity to the source text. It is also interesting to note that in commenting on their translations, the translators also point to other forms of paratextual elements in the translations, such as footnotes and glossary.

Sinha too appears to follow the path of the earlier translators in terms of her treatment of the source text. She mentions that she has adopted "a general approach of deference to the original text and its authoritative standing both locally and abroad" (Sinha, 2013, p. x). She also adds: "I have made a concerted effort to maintain the original flavour of the work through various techniques" (Sinha, 2013, p. x). For example, in relation to the author's use of culture-specific expressions in the source text which, as mentioned earlier, posed a challenge to the translator, Sinha explains: "I felt that an attempt ought to be made to preserve them, because such expressions determine and epitomize the identity of the original text" (Sinha, 2013, p. ix). Meanwhile, with regard to the use of 'bazaar Malay' by the author, Sinha also "preserved some of the more commonly-known idiomatic Malay expressions with literal translations to convey the local colour and informal register of the original" (Sinha, 2013, p. x). Sinha also mentions the author's tendency for repetitions in the source text. She, however, chooses to retain the repetitions in her translation. She asserts: "I feel justified in maintaining these to preserve the rich cultural and linguistic texture of the original" (Sinha, 2013, p. xi). She adds that she has also "retained original forms of naming and addressing characters in their traditional - sometimes even confusing - diversity in order to portray an authentic milieu" (Sinha, 2013, p. xi).

It can be seen that almost all of the translators mention the importance of retaining and preserving something of the original or of keeping close to it in their translations. Ishak too adopts a similar view. She explains that "this post- 
modern text, deeply structured within so many levels of playing, dancing and teasing with words must not only be carefully translated but the translation must retain the rhythmic movements and the musical flow of the author's narrative" (Ishak, 2004, p. viii).

Finally, while Newman uses neither the word 'retain' nor the word 'preserve', he expresses hope that his translation would be able to reflect some aspects of the original. Newman remarks that the source text is "well-written in Malay" and that "hopefully, the English style will convey both the impact and the humour of the original" (Newman 1980, p. v). This is an echo of Aveling's statement in the preface of his 1975 translation of the Malay novel Salina, in which he asserts that his aim was "to find a plain English style which would adequately reflect A. Samad Said's plain colloquial Malay" (1975, p. xiii).

The comments all appear to reflect the high regard that the translators have for the source text. It must be noted that in discussing aspects of the source text which they feel need to be retained and preserved in the translation, the translators also directly and indirectly touch upon the uniqueness of the source text and the style of the author of the text.

\subsection{The function of the prefaces}

In trying to determine the function of the prefaces, this study relies on Dimitriu's (2009) classification. According to this classification, translators' prefaces serve three different functions: (1) an explanatory function, (2) a normative/prescriptive function, and (3) an informative/descriptive function.

Based on the discussion of the translators' comments in their prefaces in the previous section, it can be said that the first four categories of comments are generally informative and descriptive in nature. The translators generally describe the difficulties they face, provide information regarding their previous translations and regarding the source text, and make special mention of certain individuals who are deemed important in the process of producing the translation.

The only comments which can be said to be generally explanatory in nature are those which are related to the general approach and specific procedures adopted in translating. As can be seen from the discussion, some of the translators not only tell the readers what they did but also present specific examples and provide justification as to why those measures were taken.

Within the same category, some comments can be said to be more informative while others are more explanatory. For example, with regard to comments relating to the origin of the translation, it appears that while Aveling's description of the origin of his translation is rather brief, Sinha's account of the history behind her translation is more elaborate and she provides a relatively detailed explanation as to how her own translation came about. In other words, while the comments in Aveling's preface with regard to the origin of the translation are generally informative, Sinha's comments regarding the same issue are more explanatory in nature.

The same can be said about comments made by the translators regarding the title of the translation. In discussing the title of his own translation, Aveling explains why a literal translation of the original would not suffice and provides more details, in fact to the point of providing the readers with the exact verse of the poem from which the title was adapted. Amin, meanwhile, provides only a literal translation of the title of her source text, with no explanation regarding the actual title chosen for her translation. In short, 
Aveling's comments about the title are more explanatory in nature compared to Amin's comments, which are brief and merely informative.

It is noted that none of the translators appear to directly prescribe a specific approach or strategy in translating a literary work. Aveling tells his readers in rather general terms that "there are many ways of translating a piece of literature, ranging from the very literal (sentence by sentence and word by word) to the very free..." (1975, p. xiii). Understandably, this fairly broad suggestion offers very little guidance to the readers on how to go about translating a literary work. The only statement that comes close to being prescriptive in nature is Sinha's assertion with regard to the treatment of culture-specific expressions in the source text. She suggests that "an attempt ought to be made to preserve them, because such expressions determine and epitomize the identity of the original text" $(2013, \mathrm{p}$. ix).

In short, the prefaces which are analysed in this study carry mainly an informative and an explanatory function. Comments which are prescriptive in nature are rare or almost non-existent in the prefaces analysed.

\section{Conclusion}

This study set out to explore translators' prefaces in some literary texts which were translated from Malay into English in Malaysia. An examination of the prefaces has shown that these metatexts appear in different forms. Most of the prefaces bear the title 'Translator's Note', and although they are of varying length, most are numbered in a way that sets them apart from the translation proper. Where content is concerned, the prefaces offered the translators the opportunity to discuss difficulties in undertaking the translation, to provide information on their own work as translators, to give specific details about the source text, and to acknowledge or express gratitude to certain individuals. The prefaces also became the perfect avenue for the translators to explain the origin of the translation, to clarify the title and to describe the general translation approach and specific procedures adopted. It can therefore be said that the prefaces examined are generally informative and explanatory in nature. Though constrained by limitations of space, the prefaces are the perfect outlet for the translators' views and opinions.

In exploring these prefaces, the study has tried to move away from the traditional focus on textual analysis, which is common in the study of translation in Malaysia. While textual analysis is no doubt important in that it may reveal the choices made by the translator, this preliminary study has shown that an analysis of the paratext may also yield information that may be useful to translator trainees, for example, by showing some of the difficulties faced by the translator and their choice of translation approach and procedures. Because prefaces contribute to the visibility of translators, an analysis of prefaces, especially one that involves a set of more comprehensive data covering different genres, publishers and a wider timespan, may offer some clues about the use of prefaces in translations. Dimitriu (2009, p. 204) asserts that "the investigation and/or elaboration of translators' prefaces, as documents placed between abstract theory and the actual practice of translation, should find a higher place up on both the scholars' and the practitioners' agenda". Prefaces, and indeed other aspects of the paratext, are worthy of further in-depth analysis as they have a lot of offer to translator trainees and researchers in the field of Translation Studies. 


\section{References}

Amin, A. (1972). [Note on the translation]. In S. Ahmad, No harvest but a thorn (p. viii). Kuala Lumpur: Oxford University Press.

Aveling, H. (1975). [Translator's note]. In A. S. Said, Salina (p. xiii). Kuala Lumpur: Dewan Bahasa dan Pustaka.

Aveling, H. (1979). [A note on the translation]. In S. Ahmad, Rope of ash (pp. xviixviii). Kuala Lumpur: Oxford University Press.

Aveling, H. (1982). [Translator's note]. In A. Ridhwan, The last days of an artist (p. v). Kuala Lumpur: Dewan Bahasa dan Pustaka.

Aveling, H. (1983). [Translator's note]. In I. Haji Muhammad, The son of Mad Mat Lela (p. x). Singapore: Federal Publications.

Dimitriu, R. (2009). Translators' prefaces as documentary sources for translation studies. Perspectives: Studies in Translatology, 17(3), 193-206.

Genette, G. (1997). Paratexts: Thresholds of interpretation (J.E. Lewin, Trans.). Cambridge: Cambridge University Press.

Hosseinzadeh, M. (2015). Translatorial prefaces: A narrative analysis model. International Journal of English Language, Literature and Translation Studies, 2(3), 311-319.

Ishak, S. (2004). [Translator's note]. In A. Ridhwan, Tales of Ogonshoto (pp. vii-xi). Kuala Lumpur: Dewan Bahasa dan Pustaka.

Kovala, U. (1996). Translations, paratextual mediation, and ideological closure. Target, 8(1), 119-147.

Marín-Dòmine, M. (2003). At first sight: Paratextual elements in the English translations of La Plaça del Diamant. Cadernos de Tradução, 1(11), 127-140.

McRae, E. (2012). The role of translators' prefaces to contemporary literary translation into English: An empirical study. In A. Gil-Bardají, P. Orero, \& S. Rovira-Esteva (Eds.), Translation peripheries: Paratextual elements in translation (pp. 63-82). Bern: Peter Lang.

Munday, J. (2009). Issues in translation studies. In J. Munday (Ed.), The Routledge companion to translation studies (pp. 1-19). London: Routledge.

Munday, J. (2016). Introducing translation studies: Theories and applications (4th ed.). London: Routledge.

Newman, B. M., Jr. (1980). [Translator's note]. In. A. Ali, Crisis (p. v). Kuala Lumpur: Dewan Bahasa dan Pustaka.

Norberg, U. (2012). Literary translators' comments on their translations in prefaces and afterwords: The case of contemporary Sweden. In A. Gil-Bardají, P. Orero, \& S. Rovira-Esteva (Eds.), Translation peripheries: Paratextual elements in translation (pp. 101-116). Bern: Peter Lang.

Paloposki, O. (2010). The translator's footprints. In. T. Kinnunen \& K. Koskinen (Eds.), Translators' agency (pp. 86-107). Tampere: Tampere University Press.

Robinson, D. (Ed.). (2002). Western translation theory from Herodotus to Nietzsche (2nd ed.). Manchester: St. Jerome.

Sanchez Ortiz, M. T. (2015). The use of footnotes in literary translation. FORUM: International Journal of Interpretation and Translation, 13(1), 111-129.

Sinha, L. (2013). [Translator's note]. In A. S. Said, Salina (pp. ix-xi). Kuala Lumpur: Institut Terjemahan \& Buku Malaysia.

Steiner, T. (1975). English translation theory: 1650-1800. Assen: van Gorcum.

Stuebing, R. B., Ishak, S., \& Mohd. Tahir, U. M. (1987). [Translator's note]. In A. T. Mohd. Hassan, Saga (n.p.). Kuala Lumpur: Dewan Bahasa dan Pustaka.

Tahir-Gürçağlar, Ş. (2002). What texts don't tell: The uses of paratexts in translation research. In. T. Hermans (Ed.), Crosscultural transgressions (pp. 44-60). Manchester: St. Jerome.

Toledano Buendía, C. (2013). Listening to the voice of the translator: A description of translator's notes as paratextual elements. Translation \& Interpreting, 5(2), 149162. 